\title{
A COMPARATIVE ANALYSIS OF ENGLISH AND LITHUANIAN TECHNICAL TERMS
}

\author{
Valerija Marina \\ Department of Foreign Languages, Vilnius Gediminas Technical University, \\ Sauletekio al.11,LT-10223 Vilnius-40,Lithuania.E-mail: lynx2@takas.lt
}

Received 7 March 2005; accepted 15 June 2005

\begin{abstract}
The paper presents a comparative analysis of English and Lithuanian metaphorical terms based on the names of the parts of human body, plants, animals, materials, clothes, utensils, etc. The analysis is aimed at identifying their common and differing features as well as spotting the specific patterns of English terms presenting difficulties for speakers of Lithuanian in their comprehension, translation and usage. It has been found that metaphorical terms are used by both languages, however, they are more common in English. The differences lie not only in the number of the respective terms but in the semantic structure as well. English terms of the models considered often do not allow for literal translation. The difficulties of their comprehension and translation may be overcome by applying the theory of linguistic relativity. Different approaches of the English and Lithuanian languages to classifying the objects of reality are also considered within the framework of linguistic relativity and some case studies are presented.
\end{abstract}

Keywords: metaphoric terms, comparative analysis, linguistic relativity, specific characteristics, similar and different patterns

\section{Introduction}

In modern knowledge and information society, the role of terminology has grown considerably. Terminology today is a source of information, a tool for acquiring special knowledge as well as carrying out research and developing new technologies.

A comparative analysis of English and Lithuanian technical terms is relevant for linguistic studies as well as for practical application, such as teaching, translation and professional activities. Mechanical, civil engineering, transport and logistics terms make an important area of terminology investigation both from theoretical and practical perspectives.

The main goal of the present research is the analysis of English technical terms and their Lithuanian equivalents aimed to identify their common and differing features as well as spotting the specific patterns of English terms presenting difficulties for speakers of Lithuanian in their comprehension, translation and usage.

The material for investigation was taken from texts and special and general dictionaries $[1,2]$.

\section{Theoretical background}

The comparative analysis of English and Lithuanian technical terms is based on the theory of linguistic relativity. This theory is focused on conceptional rather than formal differences between words and expressions of various languages showing their nationally-specific and international patterns. The former presents difficulties for comprehension and usage by the speakers of other languages.

The specific features considered are referred to conceptual differences because they are associated with specific characteristics or attributes of an object chosen by the speakers of a particular language to form a concept of this object and to name it. Every language denoting the objects depends on reality. However, this dependence may be expressed either in the same or in a different way compared to other languages. In this process many extralinguistic factors play an important part. They include differences in culture, lifestyle, history, traditions, views of the world, etc. All these social differences are reflected in languages as different patterns of forming common words and technical terms. Terms in different languages may be based on different characteristics of the same objects of reality. It is 
said that different nations view the same 'pieces of reality' from different angles and this often makes it difficult for the speakers of one language to understand terms of another language.

The analysis and identification of such cases may facilitate their understanding as well as reveal general principles of word (and term) formation.

The fact that languages differ in something more than phonetics, grammar or lexis has already been known to linguists for many years now, hence the remarks about a specific "spirit" of language (A. Gumboldt) and the "internal form" of the word (A. Potiebnia). However, a comprehensive study of this problem was conducted only by the American scientists F. Boas [3], E. Sapir [4] and B. L. Whorf [5], who developed a consistent theory of linguistic relativity in the first half of the 20-th century (cited here from later editions). It deals with the relations between language, thought and culture giving the priority to language. According to them, each language segments the reality in its own way, providing people with a particular view of the world and even affecting their behaviour, traditions and culture. The problem of the priority or interconnection of language, thought and culture or experience is not discussed here. The focus of the present study is on the ways of expressing the same concepts in English and Lithuanian with the aim of determining distinct and similar patterns and on different classification of reality by these languages. Major principles used in the present study are formulated as follows:

1. 'a given experience is differently rendered and classified in various languages';

2. 'every language is a vast pattern - system, different from other'.

These ideas are still popular in the West being considered in modern papers [6]. The theory of linguistic relativity gave a strong impetus to the development of psycholinguistics and contrastive analysis [7] continuing the study of similarities and differences between languages at different levels and from various perspectives. More recent developments may be found in the works of L. Boroditsky [8], M. Saxton and J. N. Towse [9], S. Pourcel [10], I. B. Bahar [11], etc.

Technical terms based on metaphoric transfer of meaning were analyzed because metaphor is widely used as a means of expressing scientific and technical concepts in various languages, though usually such terms have no connotation. They are mainly perceived as neutral words avoid of any emotional colouring.

The names of the parts of human body, plants, animals, materials, clothes, utensils, etc. may also denote technical mechanisms, devices and their parts, etc. because they have one or more similar features (e.g. form or function). In other words, metaphoric terms are based on associations which depend on different views and traditions of the speakers of particular languages. This, in turn, results in different patterns of terms denoting the same objects in different languages. The more unusual is the association underlying a particular term of a foreign language, the more difficult it is to understand the meaning of this term. The analysis of such cases may help not only better understand terminology of a foreign language, but can also reveal new approaches to reality and show the alternative ways of naming things, thereby developing more flexible thinking habits and the linguistic guess.

\section{Case study}

The metaphoric English terms based on the names of the parts of human body, plants, animals, utensils, etc. were taken for the analysis. They were compared with their Lithuanian translation equivalents to identify common and distinct patterns. English terms based on the parts of human body and their Lithuanian equivalents are given in Table 1.

Terms based on the names of animals are presented in Table 2.

Terms based on the names of articles and garments are given in Table 3.

Terms based on the names of plants are presented in Table 4.

As can be seen from the above examples, the names of the parts of human body, animals, plants, household articles and garments are rarely used for denoting technical devices and their parts in Lithuanian. Most English terms based on these names are translated into Lithuanian by other words. The respective Lithuanian terms are not metaphorical. It may be stated that, as far as these terms are concerned, the tradition of the Lithuanian language differs considerably from that observed in English. In Lithuanian, only few commonly used words of the above types can represent technical terms. They are: galvutè, nosis, kakliukas, auselè, alkūnè, kumštelis, pirštas (terms from group 1) and vikšras, gervè, meška (terms from group 2). Words from group 3, 4 are rarely used as technical terms in Lithuanian (the examples are: šakute, raktas).

It should also be noted that English terms based on the names of the parts of human body or the names of animals and the respective Lithuanian terms do not always match. For example: horse (Engl.) - o $\square$ ys (Lith.), fork eye (Engl.) - šakutès auselè (Lith.), monkey (Engl.) - meška (Lith.), $\operatorname{dog}($ Engl.) - kumštelis (Lith.), etc. Moreover, in one case, a Lithuanian term based on a metaphorical word was found to have an English equivalent as a neutral, unmotivated term (e.g. dantratis (Lith.) - gear (Engl.). Thus, it may be concluded that the methods of forming technical terms differ considerably in Lithuanian and English. Names of plants, animals, the parts of human body are rarely used in 
Table 1. English terms based on the parts of human body and their Lithuanian equivalents

\begin{tabular}{|c|c|c|c|}
\hline No & Term & Common meaning & Technical meaning \\
\hline 1 & $\begin{array}{l}\text { head } \\
\text { head lamp }\end{array}$ & $\begin{array}{ll}\text { galva } \\
--\end{array}$ & $\begin{array}{l}\text { galvuté, hidrostatinis slègis, prielaja } \\
\text { automobilio žibintas }\end{array}$ \\
\hline 2 & $\begin{array}{l}\text { neckshaft } \\
\text { neck }\end{array}$ & $\begin{array}{l}\text { kaklas, sprandas } \\
--\end{array}$ & $\begin{array}{l}\text { kakliukas, žiotys, krano sija, žiedinis griovelis, literos galvutè } \\
\text { veleno kakliukas }\end{array}$ \\
\hline 3 & leg & koja & atrama, stulpas, trikampio kraštinè, (el.) fazè, alkūnè, kampainis \\
\hline 4 & $\begin{array}{l}\text { lip } \\
\text { lip of tyre }\end{array}$ & $\begin{array}{l}\text { lūpa } \\
-- \\
\end{array}$ & $\begin{array}{l}\text { lūpa } \\
\text { ratlankio briauna }\end{array}$ \\
\hline 5 & $\begin{array}{l}\text { knee } \\
\text { knee brake }\end{array}$ & kelis & $\begin{array}{l}\text { (jungiamoji) alkūnè, lenktas spyris/ramstis, krica } \\
\text { alkūninis stabdys }\end{array}$ \\
\hline 6 & $\begin{array}{l}\text { nose } \\
\text { nosepiece }\end{array}$ & $\begin{array}{ll}\text { nosis } \\
--\end{array}$ & $\begin{array}{l}\text { (laivo, lèktuvo, mašinos) nosis, priekis, fasadas } \\
\text { antgalis, tūta, purkštas }\end{array}$ \\
\hline 7 & handhandrail & rankaturèklai & (laikrodžio) rodyklėlejeris \\
\hline 8 & $\begin{array}{l}\text { face } \\
\text { face grinding }\end{array}$ & $\begin{array}{ll}-- \\
\text { veidas }\end{array}$ & $\begin{array}{l}\text { briauna, ciferblatas, paviršius, nuožula } \\
\text { plokščias šlifavimas }\end{array}$ \\
\hline 9 & $\begin{array}{l}\text { thumb } \\
\text { thumb button } \\
\text { thumbscrew }\end{array}$ & $\begin{array}{l}\text { nykštis } \\
-- \\
--\end{array}$ & $\begin{array}{l}\text { sparnuotasis } \\
\text { valdymo mygtukas } \\
\text { sparnuotoji veržle }\end{array}$ \\
\hline 10 & backbone & stuburas & karkasas, pagrindas, magistrale \\
\hline 11 & $\begin{array}{l}\text { finger } \\
\text { finger alphabet }\end{array}$ & pirštas & $\begin{array}{l}\text { (laikrodžio ir pan.) rodykle, šerdesas } \\
\text { aklųjų abėcèlè }\end{array}$ \\
\hline 12 & $\begin{array}{l}\text { eye } \\
\text { fork eye }\end{array}$ & akis & $\begin{array}{l}\text { akis, auselè } \\
\text { šakutès auselè }\end{array}$ \\
\hline 13 & $\begin{array}{l}\text { elbow } \\
\text { elbow joint }\end{array}$ & alkūnė & $\begin{array}{l}\text { kampainis, alkūnė } \\
\text { alkūninis sujungimas }\end{array}$ \\
\hline 14 & shoulder & petys & kelkraštis, briaunelè, joustelè \\
\hline 15 & ear & ausis & ąsa, auselé, kilpa \\
\hline 16 & mouth & burna & žiotys, anga, išleidžiamasis/illeidžiamasis atvamzdis \\
\hline 17 & cheek & skruostas, žandas & šonas, šoninė plokštuma, žiauna \\
\hline 18 & jaw & žandas, smakras & spaustuvas, griebtuvas, žiauna, žiotys \\
\hline
\end{tabular}

Table 2. Terms based on the names of animals and parts of their body

\begin{tabular}{|c|c|c|c|}
\hline No & Term & Common meaning & Technical meaning \\
\hline 1 & $\begin{array}{l}\text { dog } \\
\text { dog clutch } \\
\text { dog screw }\end{array}$ & $\begin{array}{l}\text { šuo } \\
-- \\
--\end{array}$ & $\begin{array}{l}\text { sąvara, kumštelis, viniatraukis } \\
\text { alkūninė mova } \\
\text { fiksuojantis sraigtas }\end{array}$ \\
\hline 2 & horse & arklys, žirgas & stovas, ožys \\
\hline 3 & $\begin{array}{l}\text { tail } \\
\text { tail cup } \\
\text { dovetail }\end{array}$ & $\begin{array}{l}\text { uodega } \\
\text {-- } \\
\text { balandžio uodega }\end{array}$ & $\begin{array}{l}\text { uodega } \\
\text { uodeginis kūgis } \\
\text { kregždès uodega }\end{array}$ \\
\hline 4 & $\begin{array}{l}\text { donkey } \\
\text { donkey engine }\end{array}$ & $\begin{array}{l}\text { asilas } \\
-- \\
\end{array}$ & $\begin{array}{l}\text { pagalbinis mechanizmas, nedidele pagalbinè pompa } \\
\text { nedidelis pagalbinis variklis }\end{array}$ \\
\hline 5 & $\begin{array}{l}\text { cat } \\
\text { catwalk } \\
\end{array}$ & $\begin{array}{l}\text { katinas } \\
\text { podiumas }\end{array}$ & $\begin{array}{l}\text { atšvaistė, atošvaita } \\
\text { siauras tiltelis, klojinys }\end{array}$ \\
\hline 6 & $\begin{array}{l}\text { gooseneck } \\
\text { flexible gooseneck }\end{array}$ & $\begin{array}{l}\text { žąsies kaklas, siaura vieta } \\
--\end{array}$ & $\begin{array}{l}\text { S-formos vamzdis } \\
\text { lanksti mova }\end{array}$ \\
\hline 7 & frog & varlè & iešmo kryžma \\
\hline 8 & crab & krabas & suktuvas (gervè), krano vežimėlis, keltuvas \\
\hline 9 & monkey & beždžionė & poliakalès tvoklè, meška \\
\hline 10 & $\begin{array}{l}\text { ram } \\
\text { hydraulic ram }\end{array}$ & $\begin{array}{l}\text { avinas } \\
-- \\
\end{array}$ & $\begin{array}{l}\text { tvokle, šliaužiklis, plunžeris } \\
\text { hidraulinis taranas }\end{array}$ \\
\hline 11 & $\begin{array}{l}\text { caterpillar } \\
\text { caterpillar tractor }\end{array}$ & $\begin{array}{l}\text { vikšras } \\
--\end{array}$ & $\begin{array}{l}\text { vikšras } \\
\text { vikšrinis traktorius }\end{array}$ \\
\hline
\end{tabular}


Table 3. Terms based on the names of household articles and garments

\begin{tabular}{|c|c|c|c|}
\hline No & Term & Common meaning & Technical meaning \\
\hline 1 & button & saga & mygtukas \\
\hline 2 & key & raktas & klavišas \\
\hline 3 & sleeve & rankovè & ịvore, mova \\
\hline 4 & coat & paltas & danga, sluoksnis \\
\hline 5 & $\begin{array}{l}\text { cup } \\
\text { valve cup }\end{array}$ & puodukas & $\begin{array}{l}\text { kūgis } \\
\text { vožtuvo antgalis }\end{array}$ \\
\hline 6 & table & stalas & tekinimo skydas, ritininis konvejeris \\
\hline 7 & $\begin{array}{l}\text { shoe } \\
\text { pole shoe }\end{array}$ & batas & $\begin{array}{l}\text { (stabdžių) trinkelè, šliūžè } \\
\text { poliaus antgalis }\end{array}$ \\
\hline 8 & seat & sèdynè & (vožtuvo) lizdas, atraminis paviršius \\
\hline 9 & bed & lova & (pamatu) pagrindas, stovas \\
\hline 10 & desk & rašomasis stalas & pultas \\
\hline 11 & spoon & šaukštas & semtuvinis grąžtas \\
\hline 12 & pin & segtukas & pirštas, varžtas, šerdesas, ašis, (rakto) galvutè, barzdelè \\
\hline
\end{tabular}

Table 4. Terms based on the names of plants and their parts

\begin{tabular}{|c|l|l|l|}
\hline No & \multicolumn{1}{|c|}{ Term } & \multicolumn{1}{c|}{ Common meaning } & \multicolumn{1}{c|}{ Technical meaning } \\
\hline 1 & tree & medis & statramstis, velenas, ašis \\
\hline 2 & leaf & lapas & metalo lakštas, (durų, vartų) sąvara \\
\hline 3 & branch & šaka & atvamzdis \\
\hline 4 & cone & kankorěžis & kūgis \\
\hline 5 & nut & riešutas & veržlè, mova \\
\hline 6 & spike & varpa & smaigtis, vinis \\
\hline 7 & bush & krūmas & įdėklas, ịvorè \\
\hline
\end{tabular}

Lithuanian as a basis for technical term formation as it is common in the English language. When this method is used in Lithuanian, the particular patterns of the terms differ from those of the English language, implying that the words belonging to the same semantic groups (e.g. the parts of human body) are not equivalent in their concrete meaning (e.g. eye - auselè, dog - kumštelis, leg - alkūnè). This means that in term formation the speakers of English and Lithuanian are guided by different associations, viewing the same objects from different perspectives. Therefore, the statement of the theory of linguistic relativity that the reality is differently segmented and expressed in different languages and there are common and nationally-specific linguistic patterns, depending on views and associations of the speakers of particular languages is confirmed.

When the patterns of word formation do not match, some difficulties arise in comprehension and usage of words based on them because word-for-word translation is not possible. The linguistic analysis revealing the above conceptual differences and various approaches to nomination reflected in various languages can help to solve these problems.

\section{Classification of objects of reality in English and Lithuanian}

An attempt to identify the main principles underpinning the classification of objects of reality in English and Lithuanian has been made by analyzing technical terms belonging to the same semantic groups in these languages. In making technical translation, one is often faced with the problem of choosing the proper English equivalent of a particular Lithuanian term because several alternatives can be found in a dictionary. The analysis shows that, in many cases, multiple English words correspond to one Lithuanian term because the object named has different functions, shapes, areas of application, etc. For example, a Lithuanian term 'mova' has 19 equivalents in English (Table 5).

The same refers to the economic term 'mokestis', 'kaina'. The authors of 'Marketing' E. N. Berkowitz, R. A. Kerin and W. Rudelius [12] write about English expressions used to denote this concept in the following way: 'In the service industries, price is often referred to in various ways. Hospitals refer to charges; consultants, lawyers, physicians and accountants to fees; airlines to fares; and hotels to rates.' Thus, it may be stated that a more detailed ap- 
Table 5. An example of linguistic classification of technical items

\begin{tabular}{|l|l|}
\hline \multicolumn{1}{|c|}{ Lithuanian } & \multicolumn{1}{|c|}{ English } \\
\hline mova & coupling \\
clutch \\
sleeve \\
box \\
swivel union \\
head, pothead \\
connector \\
muff \\
joint, connection \\
adapter \\
driver \\
& coupler \\
& conduit elbow \\
& socket, ball socket \\
& nut \\
& ferrule \\
& thimble \\
& union \\
& bushing \\
\hline
\end{tabular}

proach to giving names to objects is characteristic of the English language. When some details differ, a different name is given, while in Lithuanian this aspect is not taken into consideration. Therefore, the second statement of the theory of linguistic relativity concerning different approaches to the classification of 'pieces of reality' is confirmed by the analysis of English and Lithuanian technical terms. This analysis may help to make the proper choice of the English term for the speakers of Lithuanian in difficult cases.

\section{Conclusions}

1. The analysis of English and Lithuanian terms referring to various fields of science and technology has shown that everyday words denoting parts of the human body, animals, articles, clothes, etc. are used by both languages for making technical terms. However, this method is much wider used in the English language. Thus, the words denoting home appliances and garments are practically not represented as the basis for making technical terms in Lithuanian. When such terms are formed in Lithuanian, the particular patterns often differ, not allowing for word-forword translation. An interesting observation has been made that in some cases English terms corresponding to Lithuanian metaphoric technical terms of the described type are simple unmotivated words (e.g. dantratis - gear).

2. The data obtained in the present analysis confirm the main principle of linguistic relativity stating that in various languages the same objects of reality may be denoted based on their different features which reveals the specific nature of every language. The lack of parallel patterns presents difficulties for foreign language learners, but the analysis of particular cases from the linguistic relativity perspective may facilitate the comprehension and usage of specific foreign words. Moreover, it gives the insight into a foreign language as well as helping to better understand the nature and specific features of the native language and to develop more flexible thinking habits.

3. The main principles underlying the classification of reality in the English and Lithuanian languages have been studied on the basis of technical terms. It has been found that in many cases multiple words are used in English to denote an object expressed by a single Lithuanian word. This confirms another idea of the theory of linguistic relativity that the principles of classification which are found in various languages do not by any means agree, and a set of experiences are differently grouped by different languages.

\section{References}

1. Piesarskas, B. The English-Lithuanian Dictionary (Anglųlietuvių kalbų žodynas). Vilnius: Alma Littera, 2002 (in Lithuanian).

2. The New Oxford Dictionary of English. Oxford: Clarendon Press. 1998.

3. Boas, F. Language and Culture. New York, 1966, p. 39, 181183.

4. Sapir, E. Language. New York, 1964, p. 128, 153.

5. Whorf, B. L. Language, Thought and Reality. Selected Writings. Massachusetts, USA, 1979, p. 252.

6. Lucy, J. A. Language Diversity and Thought. Cambridge University Press, 1992, p. 68.

7. James, C. Contrastive Analysis. Longman, 1999, p. 19.

8. Boroditsky, L. Does language shape thought? Mandarin and English speakers' conceptions of time. Cognitive psychology 43(1), 2001, New York, p. 1-22.

9. Matthew Saxton and John N. Towse (1998). Linguistic Relativity: The Case of Place Value in Multi-Digit Numbers. Journal of Experimental Child Psychology 69. London, p. 66-79.

10. Stéphanie Pourcel. Investigating linguistic relativity: a research methodology (in press, available online). 2001.

11. Ida Baizura Bahar. Linguistic Relativity And The Translation Dilemma: Reading Between The Lines In Malay Literatures In English (in press, available online).

12. Berkowitz, E. N. et. al. Marketing. Homewood. Boston, 1989, p. 12.

\section{ANGLŲ IR LIETUVIŲ KALBŲ TECHNIKOS TERMINŲ LYGINAMOJI ANALIZE்}

\section{Marina}

Santrauka. Straipsnyje nagrinejjami anglų kalbos technikos terminai ir jų lietuviški ekvivalentai. Analizuojami terminai yra metaforiniai ir sudaryti remiantis žmogaus kūno dalių, gyvūnų, augalų, buitinių daiktų ir drabužiu pavadinimais. Nustatyta, kad šis 
žodžių darybos metodas yra taikomas abiejose kalbose, bet anglų kalboje yra labiau paplitęs. Lietuvių kalboje terminai yra retai sudaromi naudojant buities daiktų ir rūbų pavadinimus. Bendri modeliai skiriasi ne tik sudaromų terminų skaičiumi, bet ir konkrečia semantika. Angliški terminai dažnai negali būti verčiami pažodžiui. Tai apsunkina jų supratimą ir vartojimą lietuvių kalboje. Lingvistinė reliatyvumo analizė gali palengvinti šią problemą. Taip pat buvo nagrinèjama objektų klasifikacija ịvairiose kalbose. Parodyta, kad vieną techninio objekto pavadinimą lietuvių kalboje gali atitikti keletas angliškų pavadinimų. Tai patvirtina kalbų reliatyvumo teorijos teigini, kad ìvairios kalbos atspindi skirtingus požiūrius ị realybès objektų klasifikavimą.

Raktažodžiai: metaforiniai terminai, lyginamoji analizè, kalbų reliatyvumas, ypatingos charakeristikos, panašūs ir skirtingi modeliai.

Valerija MARINA. Doctor of Humanities, Associate Professor. Department of Foreign Languages, Vilnius Gediminas Technical University.

Research interests: technical terms, semantics, the relationship between extralinguistic and linguistic aspects, linguistic relativity: theoretical issues and practical implications. 